\title{
Genes that encode botulism neurotoxins A, B, E and F in Neotropical bee honey identified with the Polymerase Chain Reaction
}

\author{
Ana Teresa Fournier ${ }^{1}$, María del Mar Gamboa ${ }^{2} \&$ María Laura Arias $^{2 *}$ \\ 1 Instituto Tecnológico de Costa Rica \\ 2 Centro de Investigación en Enfermedades Tropicales, Facultad de Microbiología, Universidad de Costa Rica; \\ mlarias@cariari.ucr.ac.cr
}

\author{
Received 22-VIII-2005. Corrected 26-IX-2005. Accepted 11-X-2005.
}

\begin{abstract}
Honey can be used for the treatment of wounds, sores and skin burns, but it might be contaminated with Clostridium botulinum spores. In order to evaluate Costa Rican raw honey samples, the detection of neurotoxin gene sequences (corresponding to the bacterium) C. botulinum A, B, E and F was done with the polymerase chain reaction. A total of 64 raw honey samples, coming from different Costa Rican sites were analyzed. Reference C. botulinum strains type A (ATCC 19397), type B (ATCC 7949), type E (ATCC 17786) and type F (ATCC 25764) were used as templates for testing the effectivity of the method. The process consisted in culturing the honey samples in prereduced triptose-peptone-glucose-yeast extract media (TGPY) for 5 days. After this, the bacteria lysate obtained was used for PCR. The amplicons, product of the reaction, were visualized using agarose gel $2 \%$. From the 64 honey samples analyzed, none produced positive results in the PCR, since no amplicons were obtained. Even though, all the reference C. botulinum strains used as controls were visualized and showed the effectivity of the extraction method and of the PCR used. The results obtained show promising therapeutic uses for honey from Costa Rica, but further evaluations shall be done in order to be sure of the safety of the product. Rev. Biol. Trop. 54(1): 29-34. Epub 2006 Mar 31.
\end{abstract}

Key words: Honey, Clostridium botulinum, PCR toxin producing genes

Honey is one of the most ancient natural medicines described, it has been used basically in the treatment of wounds, sores and skin burns. The introduction of this product as alternative medicine was empiric, and with the production of antibiotics, its use was reduced. Nevertheless, due to the appearance of antibiotics resistant strains, it has recently gained recognition in the medical field (Bogdanow 1997, Molan 1999, National Honey Board 2005).

The growth of a wide variety of microorganisms can be inhibited with honey, nevertheless, this product is the only foodstuff to date to have been associated with infantile botulism infection (Midura 1996). Also, for the time being, honey has not been associated to wound botulism, nevertheless it is a potential risk factor (Martin et al. 2003). Honey might be contaminated with $C$. botulinum spores, which eventually could germinate and grow causing a lethal infection to the patient, especially in skin and wound environments.

The detection of botulinum neurotoxins is a troublesome work, where the only universal acknowledged method is the mouse bioassay (NCFA 1991, Nevas et al. 2002), a time consuming and high cost methodology that has raised ethical concern worldwide due to laboratory animal handling. PCR appears as a screening methodology that shortens detection time, reduces costs and has good specificity and sensitivity (Szabo et al. 1993). At the same time, multiplex PCR method enables a simultaneous and specific detection of more than one serotype of $C$. botulinum, in a short time (Lindstrom et al. 2001.). 
Costa Rica is a tropical country where honey production is a growing industry. This honey may be consumed, used as food additive or in the treatment of skin wounds at national or international level. For any of these uses, the analysis of the presence of $C$. botulinum is very important. The aim of this work is to evaluate its presence in a series of raw honey samples coming either from specific apiaries or from retailers (supermarkets, free markets, salesmen) using the polymerase chain reaction.

\section{MATERIAL AND METHODS}

Sample collection: A total of 64 raw honey samples, 25 coming from Costa Rican retailers (supermarkets, free markets, salesmen) and 39 from specific apiaries, kindly provided by the Center for Research on Tropical Bees and Beekeeping (CINAT), National University (Heredia, Costa Rica), were evaluated during the months of August 2004 and January 2005, at the Food Microbiology Laboratory, University of Costa Rica.

Honey samples culture and DNA extraction: From each sample, $1 \mathrm{~g}$ was cultured in $10 \mathrm{~mL}$ prereduced triptose peptone glucose yeast extract media and incubated in anaerobic conditions at $37^{\circ} \mathrm{C}$ for 5 days. For DNA extraction, the methodology developed by Lindstrom et al. (2001) was used. Briefly, tubes that presented growth determined by turbidity were heated at $80^{\circ} \mathrm{C}$ for $5 \mathrm{~min}$ to break up the cells and release the bacterial DNA and were centrifuged for $5 \mathrm{~min}$ at $10000 \mathrm{~g}$. The supernatant was used as a template in the PCR procedure.

DNA extraction from $C$. botulinum reference strains: $C$. botulinum reference strains used included type A (ATCC 19397), type B (ATCC 7949), type E (ATCC 17786) and type F (ATCC 25764). The DNA extraction was done according to the methodology used by Hielm et al. 1996. Briefly, reference bacteria cells were cultured in prereduced cooked meat medium overnight. Cells were harvested by centrifugation at $6000 \mathrm{~g}$ for $10 \mathrm{~min}$ and resuspended in $567 \mu \mathrm{L}$ of TE buffer $(0.01 \mathrm{M}$ Tris
HCL, 0.001 M EDTA). This was added with $30 \mu \mathrm{L}$ of $10 \%$ sodium dodecyl sulfate and $3 \mu \mathrm{L}$ proteinase $\mathrm{K}(20 \mathrm{mg} / \mathrm{mL}$ in distilled water $)$ and incubated for $1 \mathrm{hr}$ at $37^{\circ} \mathrm{C}$.

After this, $100 \mu \mathrm{L} 5 \mathrm{M} \mathrm{NaCl}$ and $80 \mu \mathrm{L}$ CTAB-NaCl solution (10\% cetyl trimethyl ammonium bromide in $0.7 \mathrm{M} \mathrm{NaCl}$ ) were added and incubated for $10 \mathrm{~min}$ at $65^{\circ} \mathrm{C}$. The solution was extracted with phenol-chloroform-isoamyl alcohol (25:24:1) solution and DNA was precipitated with absolute ethanol by incubation at $-20^{\circ} \mathrm{C}$ overnight.

DNA was harvested by centrifugation at $12000 \mathrm{~g}$ for $20 \mathrm{~min}$, washed with $70 \%$ ethanol and resuspended in $100 \mu \mathrm{L}$ distilled water, after being dried at $37^{\circ} \mathrm{C}$ incubation. DNA was stored at $-20^{\circ} \mathrm{C}$.

Primers: Primers used are summarized in Table 1. They were taken from the protocol applied by Lindstrom et al. (2001), in which the primers were synthesized according to the DNA sequences of the different $C$. botulinum toxins. Four pairs of primers, specific for toxins A, B, E and F, were used.

Polymerase Chain Reaction: The PCR methodology used was based in the one used by Lindstrom et al. (2001) with some modifications. The final reaction mixture was of 25 $\mu \mathrm{L}$, containing $1 \mu \mathrm{L}$ of template, $1 \mu \mathrm{L}$ of each primer, water for PCR and a mixture for PCR $2 \mathrm{x}$ that includes Taq polymerases for DNA, $0.05 \mathrm{U} / \mu \mathrm{l}$; the deoxynucleotide triphosphates at $0.4 \mathrm{mM}$ (dATP, dCTP, dGTp and dTTP) and $\mathrm{MgCl}_{2} 4 \mathrm{mM}$ (Fermentas $(\mathbb{R})$. Reaction cycle for PCR was carried out in a Perkin Elmer GeneAmp PCR System 2400 and consisted in an initial denaturation at $95^{\circ} \mathrm{C}$ for $5 \mathrm{~min}$, 27 repetitions of denaturation at $95^{\circ} \mathrm{C}$ for 30 $\mathrm{s}$, annealing at $60^{\circ} \mathrm{C}$ for $25 \mathrm{~s}$ and extension at $72^{\circ} \mathrm{C}$ for $1 \min 25 \mathrm{~s}$. Final extension was at $72^{\circ} \mathrm{C}$ for $3 \mathrm{~min}$. The amplified PCR products were visualized in $2 \%$ agarose gels, stained with ethidium bromide. Mass Ruler DNA was used as molecular weight marker.

For testing the methodology in honey, a positive control was developed by inoculating a negative sample $(\mathrm{C} 1)$ with $0.1 \mathrm{~mL}$ of a $48 \mathrm{~h}$ culture of $C$. botulinum A reference strain. This 
TABLE 1

Primers used for the multiplex PCR detection of C. botulinum types A, B, E and $F^{*}$ (Fermentas $\left.{ }^{\circledR}\right)$

\begin{tabular}{lllcccc} 
Type & Primer & \multicolumn{1}{c}{ Sequence $\left(5^{\prime}{ }^{\prime} 3^{\prime}\right)$} & $\begin{array}{c}\text { Product size } \\
(\mathrm{bp})\end{array}$ & $\begin{array}{c}\text { Location on } \\
\text { gene (coding } \\
\text { region })\end{array}$ & $\begin{array}{c}\text { Temp } \\
\left({ }^{\circ} \mathrm{C}\right)\end{array}$ & $\begin{array}{c}\text { GC Content } \\
(\%)\end{array}$ \\
$\mathrm{A}_{\mathrm{f}}$ & CBMLA1 & AGCTACGGAGGCAGCTATGT & 782 & $1788-1808$ & 63.9 & 52 \\
$\mathrm{~A}_{\mathrm{r}}$ & CBMLA2 & CGTATTTGGAAAGCTGAAAAGG & & $2569-2548$ & 63.4 & 41 \\
$\mathrm{~B}_{\mathrm{f}}$ & CBMLB1 & CAGGAGAAGTGGAGCGAAAA & 205 & $434-453$ & 64.3 & 50 \\
$\mathrm{~B}_{\mathrm{r}}$ & CBMLB2 & CTTGCGCCTTTGTTTCTTG & & $638-619$ & 64.5 & 45 \\
$\mathrm{E}_{\mathrm{f}}$ & CBMLE1 & CCAAGATTTTCATCCGCCTA & 389 & $156-175$ & 63.7 & 45 \\
$\mathrm{E}_{\mathrm{r}}$ & CBMLE2 & GCTATTGATCCAAAACGGTGA & & $544-525$ & 63.6 & 43 \\
$\mathrm{~F}_{\mathrm{f}}$ & CBMLF1 & CGGCTTCATTAGAGAACGGA & 543 & $185-194$ & 64.1 & 50 \\
$\mathrm{~F}_{\mathrm{r}}$ & CBMLF2 & TAACTCCCCTAGCCCCGTAT & & $727-708$ & 63.3 & 55
\end{tabular}

- Taken from Lindstrom et al. 2001.

sample was cultured as described; DNA was extracted and tested by PCR. As a negative control, a sample consisting of all the reagents for PCR except DNA was analyzed.

\section{RESULTS}

From the 25 honey samples obtained from national retailers and 39 samples coming from specific apiaries, $15(60 \%)$ and 22 (56.4\%), respectively, presented growth and turbidity when cultured in prereduced triptose peptone glucose yeast extract broth under anaerobic conditions. Control strains also presented growth in cooked meat media. Gram staining showed purple rods, sporulating forms and even spores that appeared as empty spaces within a purple stain.

C. botulinum types A, B, E and F produced, by PCR, the expected amplification products. The fragments obtained for each strain correlated with the size reported for the toxin gene with the primers used, corresponding to $800 \mathrm{bp}$ for A strain, $200 \mathrm{bp}$ for B, $300 \mathrm{bp}$ for E and 500 bp for F. Nevertheless, DNA extracted from strain A represented a very big quantity of DNA, producing inhibition; therefore, 1:10,
$1: 25,1: 50$ and $1: 100$ dilutions were tested in order to obtain the expected results, as shown in figure 1.

None of the samples gave positive results for types A, B, E and F C. botulinum, neither in concentrated form nor after performing the dilutions described above (Fig. 2).

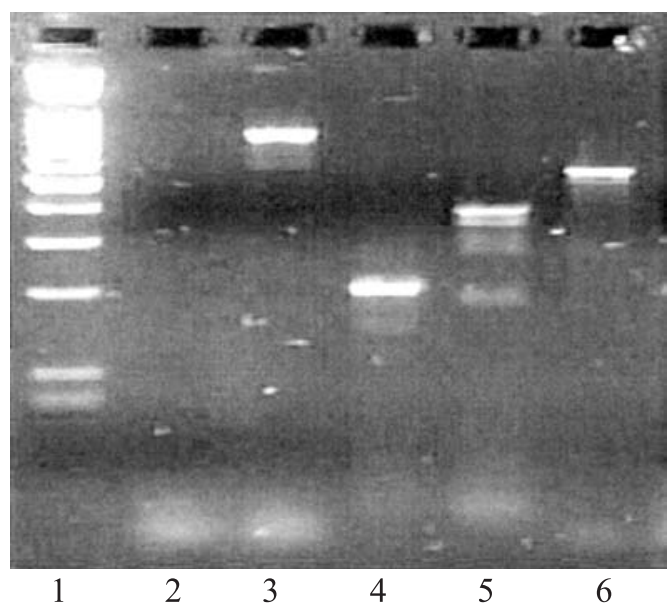

Fig. 1. PCR of control C. botulinum strains types A, B, E y F: 1) Molecular weight marker. 2) Negative control. 3) $C$. botulinum type A. 4) C. botulinum type B. 5) C. botulinum type E. 6) C. botulinum type F. 


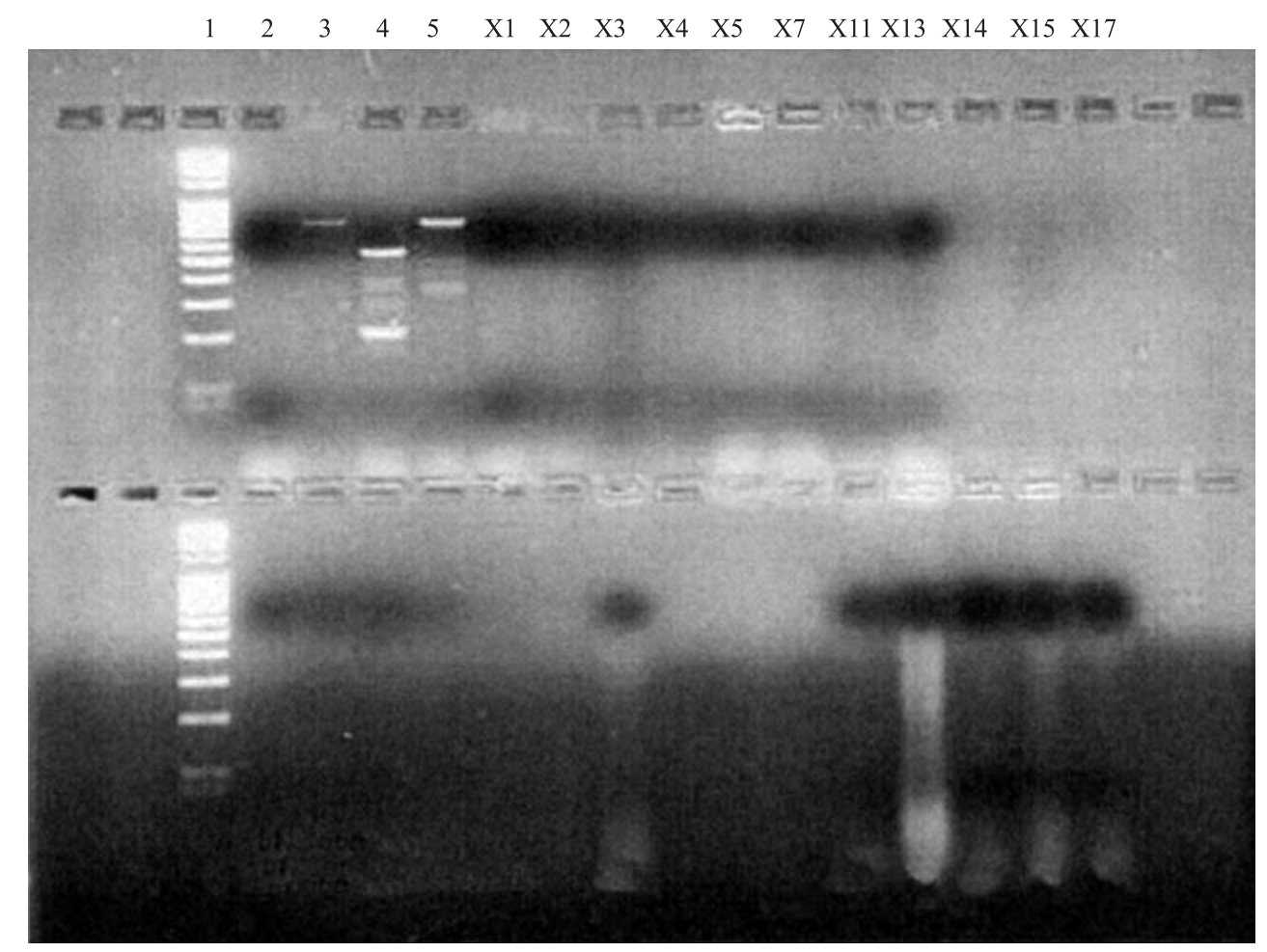

Fig. 2. PCR of the first 20 honey samples: 1 and 6) Molecular weight marker 2) Negative control 3) Clostridium botulinum type A. 4) Clostridium botulinum types B, E and F. 5) Honey samples. X1-X25 y C2-C8) Honey samples with positive culture growth.

\section{DISCUSSION}

Honey may be reintroduced in the medical field for the treatment of skin wounds, sores and skin burns as an alternative for the appearance of resistant bacterial strains. Nevertheless, because of the severity of the neuroparalytic disease caused by botulinal neurotoxins, a rapid and sensitive analysis must be performed to honey samples before any further medical use, in order to discard the possibility of C. botulinum contamination.

The first step for a reliable C. botulinum analysis is the culture of the samples. Silas et al. (1985) established that the use of an adequate culture media for this bacteria assures its development in vitro, a step necessary for further identification of the gene associated with neurotoxin production. In the present study, prereduced TPGY media was used, as described by several studies including Dahlenborg et al. (2001), Lidstrom et al. (2001) and Nevas et al. (2002).

The evaluation done with multillplex PCR allows a simultaneous, sensible and quick detection of the four types of $C$. botulinum associated to honey samples (Midura 1996). This method has a correlation rate of $95.6 \%$ with mice tests (Fach et al. 1994), so its efficiency is evident. Also, the sensitivity described for multiplex PCR assay for C. botulinum is of $10^{2}$ cells for types $\mathrm{A}, \mathrm{E}$ and $\mathrm{F}$, and 10 cells for type B (Hetland 1986).

The 64 honey samples analyzed resulted negative for the presence of $C$. botulinum, suggesting that the prevalence of this bacteria in this product is probably low in Costa Rica. There is a worldwide controversy about the prevalence of $C$. botulinum in honey samples, varying from negative results reported in France 
(Delmas et al. 1994), Germany (Hartgen 1980), Italy (Aureli et al. 1983) and Norway (Hetland 1986) to high reports including those reported by Nakano in Orient (Nakano et al. 1990) with a $16 \%$ positivity, Nevas et al. in Finland with a 7\% positivity (2002) and Solomon and Lilly (2001) that reported a 13\% occurrence of C. botulinum spores in honey samples from the United States.

Costa Rican reports, associated with C. botulinum, have been very scarce. There is a documented isolation in 1992, from a soil sample coming from Guanacaste $(\mathrm{n}=60)$, (Gamboa et al. 1993a). In 1993, a second survey reported the isolation of three strains of this bacteria, two from the Atlantic coast area and one from the Pacific coast (Gamboa et al. 1993b), although there is an absence of reported botulinum cases in Costa Rica. A similar situation occurs in other parts of Central American with reports of this bacterium in coastal regions of Nicaragua and Honduras (Ward et al. 1967), but there is a lack of reports associated to $C$. botulinum intoxication.

The medical use of honey is promising. Several recent studies show the in vitro effectivity of this product in the inhibition of different bacteria, including Escherichia coli, Staphylococcus aureus, Pseudomonas aeruginosa and S. epidiermidis (Estrada et al. 2005). This inhibitory effect occurs even at final concentrations of $25 \%$, showing an antibacterial effect further than the high sugar content or acidity of this product. At the same time, the fact that the honey samples tested are negative for $C$. botulinum is promising for further use of this product in the medical field. Nevertheless, a strict control shall be performed in the samples, in order to assure its safety for human therapeutic use.

\section{RESUMEN}

La miel de abeja es un producto que podría ser utilizado en el tratamiento de heridas, abrasiones y quemaduras de piel; no obstante, podría estar contaminada con esporas de C. botulinum. Con el fin de evaluar muestras de miel de origen costarricense, se detectó las secuencias de genes productores de neurotoxina correspondientes a C. botulinum tipos A, B, E y F utilizando la técnica de PCR (reacción de polimerasa en cadena). 64 diferentes muestras de miel, provenientes de diversos sitios costarricenses, fueron analizadas. Con el fin de evaluar la efectividad del método, se utilizó cepas de referencia tipos A (ATCC 19397), B (ATCC 7949), E (ATCC 17786) y F (ATCC 25764). El procedimiento consistió en cultivar las muestras de miel en caldo triptona peptona glucosa levadura prerreducido, por cinco días. Luego de esto, se obtuvo un lisado bacteriano, el cual fue utilizado para la técnica de PCR. Los amplicones producto de la reacción fueron visualizados utilizando geles de azarosa al 2\%. De las 64 muestras de miel analizadas, ninguna produjo resultados positivos en el PCR. No obstante, todas las cepas de referencia usadas como controles produjeron bandas, que demuestran la efectividad del método de extracción utilizado y de la técnica en sí. Los resultados obtenidos demuestran la ausencia de contaminación por C. botulinum de la miel de abeja de origen costarricense, no obstante, deben realizarse evaluaciones adicionales para garantizar la seguridad del producto.

Palabras clave: Miel, Clostridium botulinum, PCR de genes productores de toxina

\section{REFERENCES}

Aureli, P., A.M. Ferrini \& S. Negri. 1983. Ricerca delle spore di C. botulinum nel miele. Rev. Soc. Ital. Scie. Aliment. 12(6): 457-460.

Dahlenborg, M., E. Borch \& P. Radstrom. 2001. Development of a combined selection and enrichment PCR procedure for Clostridium botulinum types $\mathrm{B}, \mathrm{E}$ and $\mathrm{F}$ and its use to determinate prevalence in fecal samples from slaughtered pigs. Appl. Environ. Microbiol. 67: 4781-4788.

Delmas, C., D.J. Vidon \& M. Sebald. 1994. Survey of honey for Clostridium botulinum spores in eastern France. Food Microbiol. 11: 515-58.

Estrada, H., M. Gamboa, C. Chaves \& M.L.Arias. 2005. Evaluación de la actividad antimicrobiana de la miel de abeja contra Staphylococcus aureus, Staphylococcus epidermidis, Pseudomonas aeruginosa, Escherichia coli, Salmonella enteritidis, Listeria monocytogenes y Aspergillus niger. Evaluación de su carga microbiológica. Arch. Lat. Nut. en prensa.

Fach, P., S. Perelle, F. Dilasser, J. Grout, C. Dargaignaratz, L. Botella, J. Gourreau, F. Carlin, M. Popoff \& V. Broussolle. 1994. PCR and gene probe identification of botulinum neurotoxin A, B, E, F and G producing Clostridium spp. An evaluation in food samples. Appl. Environ. Microbiol. 61: 389-392. 
Gamboa, M, E. Rodríguez \& B. Fernández. 1993. Primer aislamiento de Clostridium botulinum en Costa Rica. Rev. Biol. Trop. 41: 2685-286.

Gamboa, M., E. Rodríguez \& B. Fernández. 1993. Clostridium botulinum en suelos de Costa Rica. Rev. Biol. Trop. 41: 359-363.

Hartgen, H. 1980. Untersuchungen vin Hinigoroben auf Botulinustoxin. Archif fur Lebensmittelhygiene 31: 1911-1917.

Hetland, A. 1986. Clostridium botulinum sporr 1 norskproduser honing? Norsk. Veterinaertidsskrift 98 725-727.

Hielm, S., E. Hyytia, J. Ridell \& H. Korkeala. 1996. Detection of Clostridium botulinum in fish and environmental sample using polymerase chain reaction. Int. J. Food Microbiol. 31: 357-365.

Lindstrom, M, R. Keto, A. Markkula, M. Nevas, S. Hielm \& H. Korkeala. 2001. Multiplex PCR assay for detection and identification of Clostridium botulinum types A, B, E and F in food and fecal material. Appl. Environ. Microbiol 67: 5694-9.

Martins, H., L. Martins \& F. Bernardo. 2003. Bacillaceae spores, fungi and aflatoxins determination in honey. Rev. Port. Cien. Vet. 98: 86-88.

Midura, T.F. 1996. Infant botulism: identification of Clostridium botulinum and its toxin in faeces. Lancet II: 934-936.

Molan, P.C. 1999. The role of honey in the management of wounds. J. Wound Care. 8: 423-426.

Nakano, H., T. Okabe, H. Hashinmoto, G. Sakaguchi. 1990. Incidence of C. botulinum in honey of various origins. Jpn. J. Med. Sci. Biol. 43: 183-195.
NCFA, Nordic Committee on Food Analysis. 1991 Clostridium botulinum: detection in foods and other test materials. NCFA Method No. 80, VTT Biotechnology and Rood Research, Espoo, Finland.

Nevas, M., S. Hielm, M. Lindstrom, H. Horn, K. Koivulehto \& H. Korkeala. 2002. High prevalence of Clostridium botulinum types A and B in honey samples detected by polymerase chain reaction. Int. J. Food Microbiol. 72: 45-52.

Silas, J.C., J.A. Carpenter, M.K. Hamdy \& M.A. Harrison. 1985. Selective and differential medium for detecting Clostridium botulinum. Appl. Environ. Microbiol. 50: 1110-1111.

Solomon, H.M. \& T. Lily. 2001. Clostridium botulinum. In : Bacteriological Analytical Manual, (Chapter 17) AOAC, Maryland, USA.

Szabo, E., J. Pemberton \& P. Desmachelier. 1993. Detection of the genes encoding botulinum neurotoxin $\mathrm{A}$ to $\mathrm{E}$ by the Polymerase Chain Reaction. Appl. Environ. Microbiol. 59: 3011-3020.

Ward, B.Q., E.S. Garrett \& G.B. Reese. 1967. Further indication of Clostridium botulinum in Latin American Waters. Appl. Microbiol. 15: 1509.

\section{INTERNET REFERENCES}

Bogdanow, S. 1997. Antibacterial substances in honey. Swiss Bee Research Center. www.Apis.admin.ch/ English/pdf/BeeProducts/AntibacterialInternet e.pdf. Downloaded August 16, 2005

National Honey Board. Honey-Health andTherapeutic Qualities. 2005. www.nhb.org/download/factsht/ compendium.pdf. Downloaded August 16, 2005. 